\title{
Identification of Single Nucleotide Polymorphism and Pathway Analysis of Apolipoprotein A5 (APOA5) Related to Fatty Acid Traits in Indonesian Sheep
}

\author{
A. Gunawan ${ }^{\mathrm{a}, *}$, D. Anggrela ${ }^{\mathrm{a}}$, K. Listyarini' ${ }^{\mathrm{a}}$, M.A. Abuzahra ${ }^{\mathrm{a}}$, Jakariaa ${ }^{\mathrm{a}}$, M. Yamin ${ }^{\mathrm{a}}$, I. Inounu ${ }^{\mathrm{b}}$, \& C. \\ Sumantri ${ }^{a}$ \\ aDepartment of Animal Production and Technology, Faculty of Animal Science, Bogor Agricultural University \\ Jalan Agatis, Kampus IPB Darmaga, Bogor 16680, Indonesia \\ ${ }^{\mathrm{b}}$ Indonesian Center for Animal Research and Development (ICARD) \\ Jalan Raya Pajajaran Kav. E-59, Bogor 16151, Indonesia \\ *Email of corresponding author: aagun4780@gmail.com \\ (Received 29-05-2018; Reviewed 27-08-2018; Accepted 05-10-2018)
}

\begin{abstract}
This study was aimed to identify single nucleotide polymorphism (SNP) and pathway analysis of APOA5 with fatty acids traits in sheep. A total of 47 rams consisted of 20 heads of Javanese Fat Tailed (JFT), 17 heads of Javanese Thin Tailed (JTT), and 10 heads of Garut Composite Sheep (GCS) were used in this study. Fatty acids traits were measured at the age of 12 months with the average body weight of 25-30 kg. Identification of polymorphism of APOA5 (g.26929941 C>T) gene were analyzed using Polymerase Chain Reaction-Restriction Fragment Length Polymorphism (PCRRFLP). The pathway analysis of APOA5 gene was performed using Kyoto Encyclopedia of Genes and Genomes (KEGG) pathway analysis. The SNP of APOA5 gene were found polymorphic with three genotypes (CC, CT, and TT). The gene frequency of CC, CT, and TT were $0.83,0.11$, and 0.06 , respectively. The chi square test revealed that the locus of APOA5 (g.26929941 C>T) was in Hardy-Weinberg equilibrium, except in thin tailed sheep. The chi-square values of JFT, JTT, and GCS were $0.05,0.03$, and 0.04 , respectively. A SNP of APOA5 was associated $(\mathrm{P}<0.05)$ with polyunsaturated fatty acids including eicosapentanoic acid (C20:5n3) and docosahexanoic (C22:6n3) and saturated fatty acid lauric acid (C12:0) in combined population (JFT, JTT, and GCS). Furthermore, pathway analysis showed that APOA5 belonged to phagosome and peroxisome proliferator-activated receptors (PPAR) signaling pathway. In conclusion, this analysis has identified APOA5 and related pathway crucial for fatty acid composition and metabolism in sheep, as well as this gene provide molecular marker to select sheepmeat with high unsaturated fatty acid.
\end{abstract}

Keywords: APOA5, unsaturated fatty acid, garut composite sheep, javanese fat tailed sheep, javanese thin tailed sheep

\section{INTRODUCTION}

The quality of meat is largely affected by its fat content and fatty acid (FA) composition. Fatty acid composition and fat content are also important components for consumer health (Siri-Tarino et al., 2015; Chowdurry et al., 2015). Ruminant meats including sheep meat are important components of the human diet and health to be a relevant factor in consumers' meat preference. Sheep meat contains higher saturated fatty acids than beef (Bahar, 2003) which limited the consumption level of this meat. Consumption of ruminant-derived fat is directly associated the negative effects of fat on human health because it is one source of cholesterol (Soeparno, 2011). Fatty acids (FAs) are classified mostly according to the presence or absence of double bonds as saturated fatty acid (SFAs-without double bonds), monounsaturated (MUFAs - with one double bond), and polyunsaturated fatty acids (PUFAs - with two or up to six double bonds (Orsavova et al., 2015). In animal products the proportion of polyunsaturated FAs (PUFAs) is considered by consumers as an important factor for dietetic value of the meat (Perez et al., 2010). Production of meat with high PUFA and low SFA content is beneficial for human health and it more in line with public health recomendation. Identification of genetic factors controlling fatty acids composition could be implemented in genetic improvement to select animals that produce high PUFA and low SFA levels.

The genetic improvement has been accompolished mainly through the use of molecular-genetic selection approach. Molecular-based selection through the identification of Single Nucleotida Polymorphism (SNP) mutation points is considered quite accurate because it can link between genes and properties to be selected for later development in sheep breeding. The genetic variation and differences among individuals could be detected by SNPs charaterization (Aslam et al., 2012). Identification of the SNP-based polymorphism is commonly used to see the genetic variation of gene encoding certain traits. 
One important gene which contribute to fatty acid traits is the apolipoprotein A5 (APOA5) gene. The APOA5 is located on chromosome 15 in sheep which is an important regulator of triglyceride rich lipoprotein (TLR) metabolism (Fruchart et al., 2004). APOA5 is expressed exclusively by the liver and is secreted into the plasma in a very low concentration. APOA5 facilitates the binding of VLDL to the vascular endothelium close to lipoprotein lipase (LPL) releases of fatty acid into skeletal muscle and adipose tissue (Jasim et al., 2017).

Several common SNPs of APOA5 have been associated with the increase of total plasma triglyceride (TG), plasma remnant-like particle (RLP), and very low density lipoprotein (VLDL) (Carannza-Gonzalez et al., 2017; Jasim et al., 2017). Moreover, Lai et al. (2006) reported that APOA5 associated with postprandial lipemia that could be modulated by the type of dietary fat through polyunsaturated fatty acid (PUFAs). High n-6 PUFA intake increased fasting TGs, RLP concentrations, and VLDL size and decreased LDL size in APOA5 (Martin et al., 2013). Notably, no study investigated SNP of APOA5 in sheep with regard to fatty acid traits. However, functional and positional studies suggested that these genes could be important candidate genes for fatty acid composition. This study aims to identify single nucleotide polymorphism (SNP) and pathway analysis of APOA5 with fatty acids traits in sheep.

\section{MATERIAL AND METHODS}

\section{Animals Care and Phenotype}

The experimental procedure was approved by the Institutional Animal Care and Use Committee (IACUC) at Bogor Agricultural University (approval ID: 117-2018 IPB). Forty seven Indonesian sheeps including Javanese Fat Tailed (JFT, n= 20), Javanese Thin Tailed (JTT, n= 17), and Garut Composite (GCS, n=10) sheep were used in this study. The sheep were kept in group with ad libitum fattening feed. Samples were taken from loin muscle and phenotypes were collected from the rams JFT $(\mathrm{n}=$ $25)$, JTT $(n=17)$, and GCS $(n=10)$ with body weights range of $25-30 \mathrm{~kg}$ and age range of $10-12$ months. The animals were slaughtered in the slaughter house according to the standard operasional procedure provided in the house. The loin muscle were taken approximatelly $500 \mathrm{mg}$ for faty acid (FA) analysis and $30 \mathrm{mg}$ loin for DNA extraction. All the samples for the DNA extraction were immediately placed in ice and kept at $-20^{\circ} \mathrm{C}$ until futher usages.

\section{Analysis of Fatty Acid Composition}

Fatty acid composition was determined for each sample using the extraction method according to Folch et al. (1957). Muscle samples ( 100 g) were collected and grounded for fatty acid composition. The lipids were extracted by homogenizing the sample with a chloroform and methanol (2:1) solution and $1.5 \% \mathrm{NaCl}$ was added and so that the lipids were isolated. The isolated lipids were methylated and the methyl esters (FAMEs= Fatty
Acid Methyl Esters) were prepared from the extracted lipids with BF3-methanol (Sigma-Aldrich, St. Louis, MO, USA) and separated on a gas chromatograph (Hewlett-Packard, Palo Alto, CA, USA) as was described previously (Jeong et al., 2011).

\section{Quantification of Fatty Acids Using Gas- Chromatography (GC)}

The loin muscle were taken approximatelly $500 \mathrm{mg}$ for faty acid (FA) analysis. GC analysis was carried out using an Shimadzu GC 2010 Plus (Shimidzu Scientific Instruments, Japan), equipped with a Quadrex capillary column (30 m_ $0.25 \mathrm{~mm} \_0.25 \mu \mathrm{m}$; flow, $\left.1 \mathrm{~mL} / \mathrm{min}\right)$ using helium as carrier gas. The temperature program was as follows: start at $125^{\circ} \mathrm{C}$, hold for $5 \mathrm{~min}$, then raised to $185^{\circ} \mathrm{C}$ at $30^{\circ} \mathrm{C} / \mathrm{min}$, subsequently raised to $205^{\circ} \mathrm{C}$ at 5 ${ }^{\circ} \mathrm{C} / \mathrm{min}$, hold for $5 \mathrm{~min}$, finally raised to $225^{\circ} \mathrm{C}$ at $20^{\circ} \mathrm{C} /$ min, and hold for 10 min. Fatty acids analysis was done according to Association of Official Analytical Chemists (AOAC, 2012). These measurements included fat content (FC), saturated fatty acids (SFA), monounsaturated fatty acids (MUFA), polyunsaturated fatty acids (PUFA), and total fatty acids (TFA) .

\section{DNA Extraction and PCR-RFLP Amplification}

DNA was isolated from skeletal muscle tissue of Indonesian sheep according to the standard phenolchloroform method. DNA extraction was started with the removal of loin tissue. Then, the collected tissue was extracted according to Sambrook \& Russel (2001) protocols. The SNP of APOA5 used in this study were based on a RNA sequencing study (Gunawan et al., 2018). The prepared libraries were sequenced in an Illumina HiSeq 2500 as single-reads to $100 \mathrm{bp}$ using 1 lane per sample on the same flow-cell (first sequencing run) at Macrogen Inc, South Korea. APOA5 gene fragment amplification were conducted using the GeneAmp PCR system ESCO. A total of two pairs of primers were designed in MEGA 6.0 and checked the profile using Primer Stat. These primers (5'-CTG CAC AGG ATA GCT GGA GC -3'and 5'- GAC CAG ACC CTG GGA TAA AG -3)' were designed to amplify a 258-bp fragment by primer stat according to the sheep genomic sequence in the GenBank database (accession number CM_001596.1). The Polymerase Chain Reaction (PCR) were performed under the following condition: initial denaturing at $94{ }^{\circ} \mathrm{C}$ for $5 \mathrm{~min}$ followed by 35 cycles of $30 \mathrm{~s}$ at $94{ }^{\circ} \mathrm{C}, 30 \mathrm{~s}$ at $60{ }^{\circ} \mathrm{C}$ and $1 \mathrm{~min}$ at $72{ }^{\circ} \mathrm{C}$ and a final elongation of $10 \mathrm{~min}$ at $72{ }^{\circ} \mathrm{C}$. The DNA amplification product 258 bp was visualized by $1.5 \%$ agarose gel electrophoresis.

PCR-RFLP were used for genotyping SNP of APOA5. PCR product and restriction enzymes BssS1 were incubated at $37^{\circ} \mathrm{C}$ for $4 \mathrm{~h}$ (Thermo Fisher Scientific, EU, Lithuana). An aliquot of the PCR product of each reactions were checked on 1.5\% agarose gel (Fisher Scientific Ltd.) before digestion using endonucleases BssS1 for APOA5 gene. The digested products were separated using $2.0 \%$ agarose gel which was stained with 
FluoroSafe. The fragments were visualized under UV Transilluminator (Alpha Imager, Alpha Innotech, Santa Clara, USA).

\section{Statistical Analysis}

Genotype and allele frequencies. The genotype and allele frequencies were analyzed using genotyping data based on the populations of three populations (JFT, JTT, and GCS) sheep. Genotype frequency was calculated by the following formula according to Nei \& Kumar (2000):

$$
x_{i i}=n_{i i} / N
$$

Allele frequency was calculated by the following formula:

$$
x_{i}=\left(2 n_{i i}+\sum n_{i j}\right) / 2 N
$$

where $X_{i i}$ is the ii-th genotype frequency, $X_{i}$ is the i-th allele frequency, $n_{i j}$ is the number of the sample of $i_{i}$ genotype, $n_{i j}$ is the number of the sample of $i_{i}$ genotype, and $N$ is the total samples.

Association study. The association between the SNP of APOA5 and fatty acid trait was performed using the GLM procedure (SAS Inst. Inc., Cary, NC). The model was fitted with the genotype (Genotype; 3 levels; CC, $\mathrm{CT}$, and TT) and breed (Breed; JFT, JTT, and GCS) as fixed effects, as follows:

$$
Y_{i j k}=\mu+\text { genotype }_{i}+\text { breed }_{j}+\mathrm{e}_{i j k}
$$

where $Y$ is the dependent variable for trait measured in the population, $\mu$ is the overall population mean for traits, genotype is the fixed effects, breed is breed effects, and $e$ is the random error. A p-value of $<0.05$ was considered statistically significant. Least square mean values for the loci genotypes were compared by t-test and $\mathrm{p}$-values were adjusted by the Tukey-Kramer correction (Gunawan et al., 2012; Cinar et al., 2012; Gunawan et al., 2011).

Pathways and networks analysis. Biological pathways and network analysis of APOA5 gene were identified by KEGG pathway analysis using Cytoscape software (version 2.6.2) (http://www.cytoscape.org/) with the ClueGO plugin (http:// www.ici.upmc.fr/cluego/cluegoDownload.shtml) (Bindea et al., 2009).

\section{RESULTS}

\section{Phenotypic of Meat Fatty Acid Composition Profile of Indonesian Sheep}

Fatty acid composition of loin muscle from Javanese Fat Tailed (JFT), Javanese Thin Tailed (JTT), and Garut Composite (GCS) as well as combined population (JFT, JTT, and GCS) are presented in Table 1. Sixteen fatty acid composition including total SFA, PUFA, and MUFA were detected in each of the sample. There were 7 types of fatty acids in SFA (C12; C14; C15; C16; C17; C18; C20), 4 types of fatty acids in MUFA (C14:1; C16:1; C18:1; C18:1n9c), and 5 types fatty acids in PUFA (C18:2n6c; C20:2; C20:4n6; C20:5n3; C22:6n3).

\begin{tabular}{|c|c|c|c|c|}
\hline Variable & $\begin{array}{c}\text { JFT, JTT, and GSC } \\
(\mathrm{n}=47)\end{array}$ & JFT $(n=20)$ & JTT (n=17) & GCS $(n=10)$ \\
\hline Fat content of meat & $5.60 \pm 3.65$ & $7.08 \pm 4.01^{\mathrm{a}}$ & $6.01 \pm 2.72^{\mathrm{a}}$ & $1.95 \pm 0.91^{b}$ \\
\hline Fatty acid total of fat content & $70.15 \pm 5.87$ & $70.01 \pm 6.09$ & $70.98 \pm 5.69$ & $68.23 \pm 5.94$ \\
\hline Saturated Fatty Acid (SFA) & $37.69 \pm 6.20$ & $35.10 \pm 6.68^{\mathrm{b}}$ & $38.49 \pm 4.68^{\mathrm{ab}}$ & $41.53 \pm 5.53^{a}$ \\
\hline Lauric Acid (C12:0) & $0.47 \pm 0.61$ & $0.68 \pm 0.89$ & $0.29 \pm 0.19$ & $0.35 \pm 0.10$ \\
\hline Myristic acid (C14:0) & $3.33 \pm 2.11$ & $3.55 \pm 2.64^{\mathrm{a}}$ & $3.77 \pm 1.82^{\mathrm{a}}$ & $2.14 \pm 0.38^{b}$ \\
\hline Pentadecanoic Acid (C15:0) & $0.49 \pm 0.15$ & $0.45 \pm 0.17$ & $0.56 \pm 0.13$ & $0.49 \pm 0.10$ \\
\hline Palmitic Acid (C16:0) & $18.63 \pm 2.78$ & $18.73 \pm 2.65^{\mathrm{a}}$ & $19.92 \pm 2.31^{\mathrm{a}}$ & $16.26 \pm 2.37^{b}$ \\
\hline Heptadecanoic Acid (C17:0) & $1.08 \pm 0.37$ & $1.20 \pm 0.47 a$ & $1.10 \pm 0.21^{\mathrm{a}}$ & $0.80 \pm 0.08^{b}$ \\
\hline Stearic Acid (C18:0) & $13.60 \pm 5.13$ & $10.43 \pm 2.80^{c}$ & $12.78 \pm 3.20^{\mathrm{b}}$ & $21.33 \pm 3.13^{a}$ \\
\hline Arachidic Acid (C20:0) & $0.09 \pm 0.05$ & $0.06 \pm 0.02^{\mathrm{b}}$ & $0.07 \pm 0.03^{b}$ & $0.16 \pm 0.03^{\mathrm{a}}$ \\
\hline Monounsaturated Fatty Acid (MUFA) & $29.36 \pm 4.95$ & $32.24 \pm 3.17^{a}$ & $30.10 \pm 3.17^{b}$ & $22.43 \pm 2.87^{c}$ \\
\hline Myristoleic Acid (C14:1) & $0.13 \pm 0.07$ & $0.16 \pm 0.08^{\mathrm{a}}$ & $0.13 \pm 0.05^{\mathrm{a}}$ & $0.07 \pm 0.03^{b}$ \\
\hline Palmitoleic Acid (C16:1) & $1.64 \pm 0.38$ & $1.90 \pm 0.25^{\mathrm{a}}$ & $1.61 \pm 0.31^{\mathrm{b}}$ & $1.17 \pm 0.19 c$ \\
\hline Elaidic Acid (C18:1n9t) & $0.09 \pm 0.10$ & $0.07 \pm 0.08^{\mathrm{b}}$ & $0.20 \pm 0.08^{\mathrm{a}}$ & $0.00 \pm 0.00^{c}$ \\
\hline Oleic Acid (C18:1n9c) & $27.50 \pm 4.50$ & $30.11 \pm 2.98^{\mathrm{a}}$ & $28.16 \pm 3.06^{\mathrm{a}}$ & $21.18 \pm 2.70^{\mathrm{b}}$ \\
\hline Polyunsaturated Fatty Acid (PUFA) & $3.10 \pm 1.42$ & $2.67 \pm 1.32^{\mathrm{b}}$ & $2.38 \pm 1.05^{\mathrm{b}}$ & $4.27 \pm 1.43^{\mathrm{a}}$ \\
\hline Linoleic Acid (C18:2n6c) & $2.25 \pm 0.94$ & $2.26 \pm 0.90$ & $1.77 \pm 0.82$ & $3.05 \pm 0.71$ \\
\hline Eicosedienoic Acid (C20:2) & $0.04 \pm 0.02$ & $0.05 \pm 0.02^{\mathrm{a}}$ & $0.03 \pm 0.01^{b}$ & $0.04 \pm 0.004^{\mathrm{ab}}$ \\
\hline Arachidonic Acid (C20:4n6) & $0.48 \pm 0.46$ & $0.32 \pm 0.25^{b}$ & $0.31 \pm 0.22^{b}$ & $1.07 \pm 0.60^{\mathrm{a}}$ \\
\hline Eicosapentanoic Acid (C20:5n3) & $0.29 \pm 0.07$ & $0.03 \pm 0.05^{\mathrm{a}}$ & $0.20 \pm 0.16^{\mathrm{b}}$ & $0.06 \pm 0.01^{\mathrm{a}}$ \\
\hline Docosahexaaonic (C22:6n3) & $0.04 \pm 0.05$ & $0.01 \pm 0.02^{\mathrm{a}}$ & $0.07 \pm 0.05^{\mathrm{a}}$ & $0.05 \pm 0.03^{b}$ \\
\hline
\end{tabular}
Statistical analysis showed that different breeds har-

Table 1. Phenotypic of meat fatty acid composition of Indonesian sheep (\%)

Note: a,b,c Means in the same row with different superscripts differ significantly $(\mathrm{P}<0.05)$. Numbers shown in parentheses are the number of individuals with the specified genotype. 
bours different profiles of fatty acids, particullary C14:0; C14:1; C16:0; C16:1; C17:0; C18:0; C18:1n9t; C18:1n9c; C18:2n6c; C20:0; C20:2; C20:4n6; C20:5n3; C22:6n-3. The SFA presented lower values in the JFT sheep when compared to the other two breeds. The result also showed total MUFA was higher than PUFA (Table 1). The major fatty acid in total SFA was palmitic acid (C16). The major fatty acid in total MUFA was oleic acid ( C18:1n9c). The fatty acid linoleic acid (C18: 2n6c) was dominant among the total PUFA.

\section{A Single Nucleotide Polymorphism APOA5 Gene}

The 258 bp fragment of APOA5 (g.26929941 C>T) gene was succesfully amplified as shown in Figure 1. Three genotypes were detected and defined as CC, CT, and TT (Figure 2). The $258 \mathrm{bp}$ fragment was succesfully digested with BssS1 restriction enzyme. The digested PCR products had fragment sizes of 159 and 99 bp for the CC genotype; and 258, 159, and $99 \mathrm{bp}$ for the CT genotype; and $258 \mathrm{bp}$ for the TT genotype (Figure 2). The $\mathrm{T}$ allele was very rare in JFT sheep with the frequency of 0.05 , whereas JTT and GCS showed T allele with the frequencies of 0.17 and 0.15 respectively. The SNP of APOA5 (g.26929941 C>T) was not detected in Hardy Weinberg Equlibrium (HWE), except JTT sheep. The number of animals per genotype and allele frequency of the SNP is presented in Table 2.

\section{Association between APOA5 Gene Polymorphism and Fatty Acids Traits}

Due to the the genotipe CT and TT were not segregated in all populations and also the low frequency of $\mathrm{T}$ in JFT and GSC samples, the association study between SNP of APOA5 and fatty acid trait was performed in combined population (JFT, JTT, and GCS). The association of APOA5 gene polymorphism and fatty acid traits in combined (JFT, JTT, and GCS) sheep were summarized in Table 3. The g.26929941 C>T SNP of

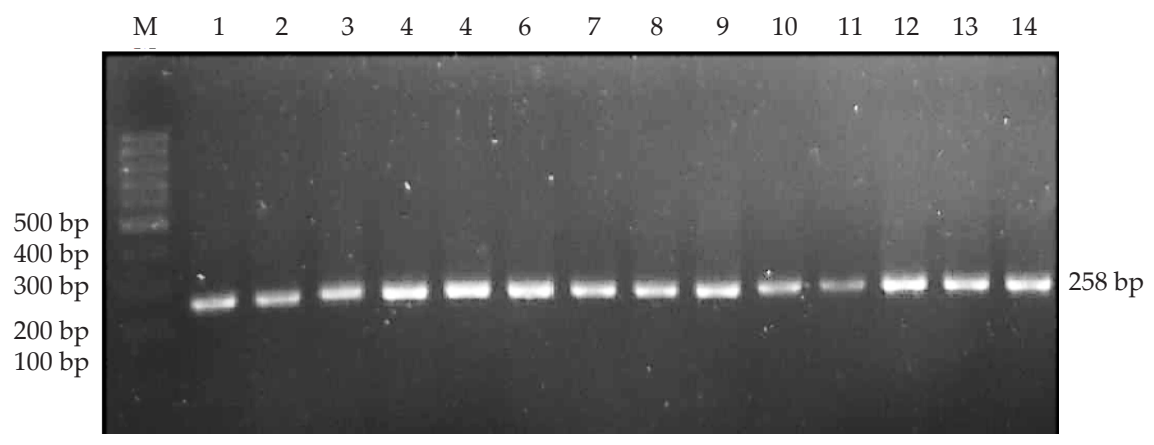

Figure 1. Amplification result of PCR for the APOA5 gene. $M=100$ bp ladder size standard; Line 1-14 = Individual sample of sheep.

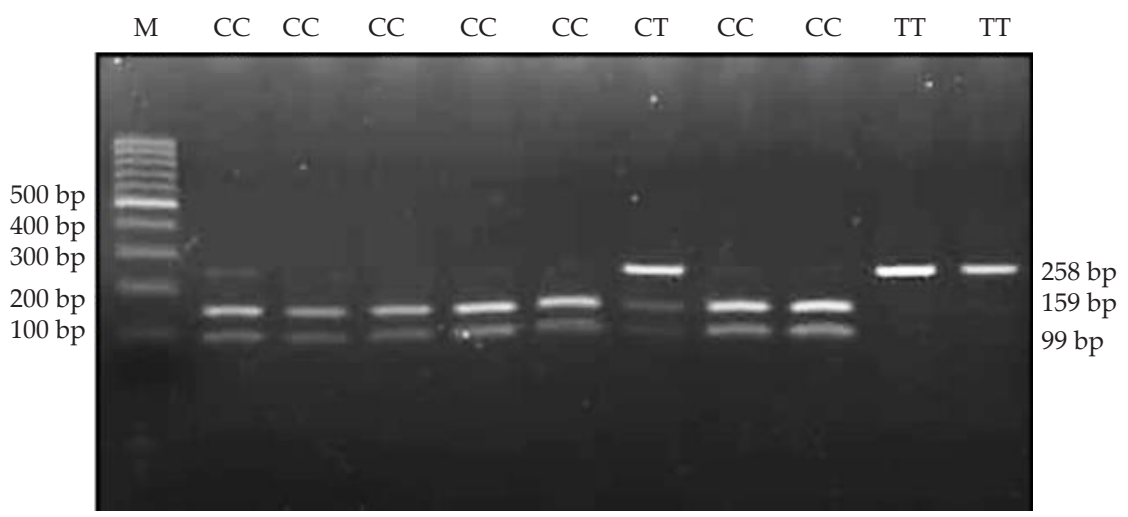

Figure 2. The PCR-RFLP pattern for APOA5 gene with BssSI restriction enzyme. $\mathrm{M}=$ 100bp markers; $1,2,3,5,7,8=$ AA genotype; $9,10=$ TT genotype; $6=\mathrm{CT}$ genotype .

Table 2. Genotype and allele frequencies of APOA5 gene g.37284C >T SNP in Indonesian sheep

\begin{tabular}{|c|c|c|c|c|c|c|c|}
\hline \multirow{2}{*}{ Sample } & \multirow{2}{*}{$\mathrm{N}$} & \multicolumn{3}{|c|}{ Genotype frequency } & \multicolumn{2}{|c|}{ Allele frequency } & \multirow{2}{*}{$\begin{array}{c}\text { Chi-quadrat } \\
\left(\chi^{2}\right)\end{array}$} \\
\hline & & $\mathrm{CC}$ & $\mathrm{CT}$ & TT & $\mathrm{C}$ & $\mathrm{T}$ & \\
\hline Fat tailed sheep (JFT) & 20 & $0.90(18)$ & $0.10(2)$ & $0.00(0)$ & 0.95 & 0.05 & $0.01^{*}$ \\
\hline Thin tailed sheep (JTT) & 17 & $0.82(14)$ & $0.000(0)$ & $0.18(3)$ & 0.83 & 0.17 & $1.00^{\mathrm{ns}}$ \\
\hline Garut composite sheep (GCS) & 10 & $0.70(7)$ & $0.30(3)$ & $0.00(0)$ & 0.85 & 0.15 & $0.03^{*}$ \\
\hline Combined JFT, JTT, and GCS & 47 & $0.83(39)$ & $0.11(5)$ & $0.06(3)$ & 0.88 & 0.12 & $0.21^{*}$ \\
\hline
\end{tabular}

Note: * significant at $\mathrm{P}<0.05 ; \mathrm{ns}=$ not significant. 
Table 3. Genotype and association analysis of APOA5 gene (\%)

\begin{tabular}{|c|c|c|c|}
\hline \multirow[b]{2}{*}{ Variables } & \multicolumn{3}{|c|}{ Genotype } \\
\hline & $\begin{array}{c}\mathrm{CC} \\
(\mathrm{n}=39)\end{array}$ & $\begin{array}{c}\mathrm{CT} \\
(\mathrm{n}=5)\end{array}$ & $\begin{array}{c}\mathrm{TT} \\
(\mathrm{n}=3)\end{array}$ \\
\hline Fat content & $5.93 \pm 0.59$ & $4.16 \pm 2.65$ & $5.74 \pm 2.65$ \\
\hline Fatty acid total of fat & $70.15 \pm 0.09$ & $70.73 \pm 4.41$ & $68.86 \pm 4.41$ \\
\hline Saturated Fatty Acid (SFA) & $36.70 \pm 1.03$ & $42.05 \pm 4.59$ & $36.62 \pm 4.59$ \\
\hline Lauric Acid (C12:0) & $0.42 \pm 0.04^{\mathrm{b}}$ & $1.79 \pm 0.41^{\mathrm{a}}$ & $0.46 \pm 0.41^{\mathrm{b}}$ \\
\hline Myristic Acid (C14:0) & $3.21 \pm 0.33$ & $5.97 \pm 1.48$ & $5.09 \pm 1.48$ \\
\hline Pentadecanoic Acid (C15:0) & $0.08 \pm 0.01$ & $0.09 \pm 0.01$ & $0.10 \pm 0.06$ \\
\hline Palmitic Acid (C16:0) & $18.69 \pm 1.71$ & $18.61 \pm 2.05$ & $19.34 \pm 2.05$ \\
\hline Heptadecanoic Acid (C17:0) & $1.12 \pm 0.06$ & $0.70 \pm 0.27$ & $0.94 \pm 0.27$ \\
\hline Stearic Acid (C18:0) & $13.09 \pm 0.81$ & $14.78 \pm 3.61$ & $10.62 \pm 3.61$ \\
\hline Arachidic Acid (C20:0) & $0.09 \pm 0.01$ & $0.11 \pm 0.04$ & $0.07 \pm 0.04$ \\
\hline Monounsaturated Fatty Acid (MUFA) & $30.41 \pm 0.78$ & $24.81 \pm 3.49$ & $29.36 \pm 3.49$ \\
\hline Myristoleic Acid (C14:1) & $0.13 \pm 0.01$ & $0.19 \pm 0.05$ & $0.21 \pm 0.05$ \\
\hline Palmitoleic Acid (C16:1) & $1.67 \pm 0.06$ & $1.63 \pm 0.27$ & $1.80 \pm 0.27$ \\
\hline Elaidic Acid (C18:1n9t) & $0.53 \pm 0.06$ & $0.32 \pm 0.27$ & $0.26 \pm 0.27$ \\
\hline Oleic Acid (C18:1n9c) & $28.08 \pm 0.70$ & $22.67 \pm 3.15$ & $27.09 \pm 3.15$ \\
\hline Polyunsaturated Fatty Acid (PUFA) & $2.83 \pm 0.23$ & $3.87 \pm 1.05$ & $2.88 \pm 1.82$ \\
\hline Linoleic Acid (C18:2n6c) & $2.46 \pm 0.16$ & $2.23 \pm 0.70$ & $1.98 \pm 0.70$ \\
\hline Eicosadienoic Acid (C20:2) & $0.05 \pm 0.003$ & $0.05 \pm 0.01$ & $0.03 \pm 0.01$ \\
\hline Arachidonic Acid (C20:4n6) & $0.45 \pm 0.07$ & $0.55 \pm 0.34$ & $0.52 \pm 0.34$ \\
\hline Eicosapentanoic Acid (C20:5n3) & $0.05 \pm 0.01^{\mathrm{b}}$ & $0.02 \pm 0.05^{\mathrm{b}}$ & $0.23 \pm 0.05^{\mathrm{a}}$ \\
\hline Docosahexanoic (C22:6n3) & $0.03 \pm 0.01^{\mathrm{b}}$ & $0.02 \pm 0.03^{\mathrm{b}}$ & $0.12 \pm 0.01^{\mathrm{a}}$ \\
\hline
\end{tabular}

Note: ${ }^{\mathrm{a}, \mathrm{b}, \mathrm{c}}$ Means in the same row with different superscripts differ significantly $(\mathrm{P}<0.05)$. Numbers shown in parentheses are the number of individuals with the specified genotype.

APOA5 gene was generally significantly associated with fatty acids composition in combined population (Table 3). There were significant associations between the APOA5 polymorphism and polyunsaturated fatty acids (PUFA) including eicosapentanoic acid (C20:5n3) and docosahexanoic (C22:6n3), and saturated fatty acid lauric acid (C12:0) (Table 3). Sheeps with homozygous 'TT' genotype were associated with higher polyunsaturated fatty acids [eicosapentanoic acid (C22:6n3), and docosahexanoic acid (C22:6n3)] and lower saturated fatty acid [lauric acid (C12:0)] (Table 3). However, this association should be confirmed and validated in larger population with different sheep breeds.

\section{Pathway Analysis and Network of APOA5 Gene}

The Kyoto Encyclopedia of Genes and Genomes (KEGG) pathway analysis showed that APOA5 gene involved in the cascades signaled by phagosome and peroxisome proliferator-activated receptors (PPAR) signaling pathway which is important for fatty acid metabolism (Figure 3). There are three members of the PPAR family (PPARalpha, beta/delta, and gamma) with different expression patterns in adipocyte and skeletal muscle (Figure 3).

\section{DISCUSSION}

The most abundant saturated fatty acid in muscle was $\mathrm{C} 16: 0$ in all three breeds of sheep, in accordance with the other studies (van Harten et al., 2014; Wilkes et al., 2012). This fatty acid was also affected by breed: The SFA presented lower values in the JFT sheep when compared to the other two breeds (Table 1). These results are in agreement with previous study by van Harten et al., (2014) that examined breed effect on fatty acid composition in different three breeds population (Dorper, Damara, and Merino). The differences between breed could be hypothesised that the results could be explained by the difference in intramuscular fat deposition between breeds, since the JFT store fat in their tails and therefore tend to have lower amounts of carcass and intramuscular fat (Yousefi et al., 2012; Almeida, 2011). Another explanation for the differences in fat deposition between breeds could putatively be related to their growth rates (Juarez et al., 2008). JFT sheep is predicted had higher growth rates than JTT and GCS sheep. In accordance with data from previous studies by Sun et al., (2016) and Wang et al., (2014) which compared between fat and thin tailed sheep, could be masked by the morphological and size differences between these breeds.

The polymorphism study of APOA5 gene fragment was succesfully amplified using PCR from all samples. The genotype and allele frequencies were calculated in Indonesian sheep (JFT, JTT, and GCS) (Table 2). There were three genotypes (CC, CT, and TT) and two alleles $(\mathrm{C}$ and $\mathrm{T})$ found in three sheep populations. The CC genotype was the highest genotype frequency in all population. The $\mathrm{C}$ allele was more frequent than $\mathrm{T}$ allele in three populations). Previous study conducted by 


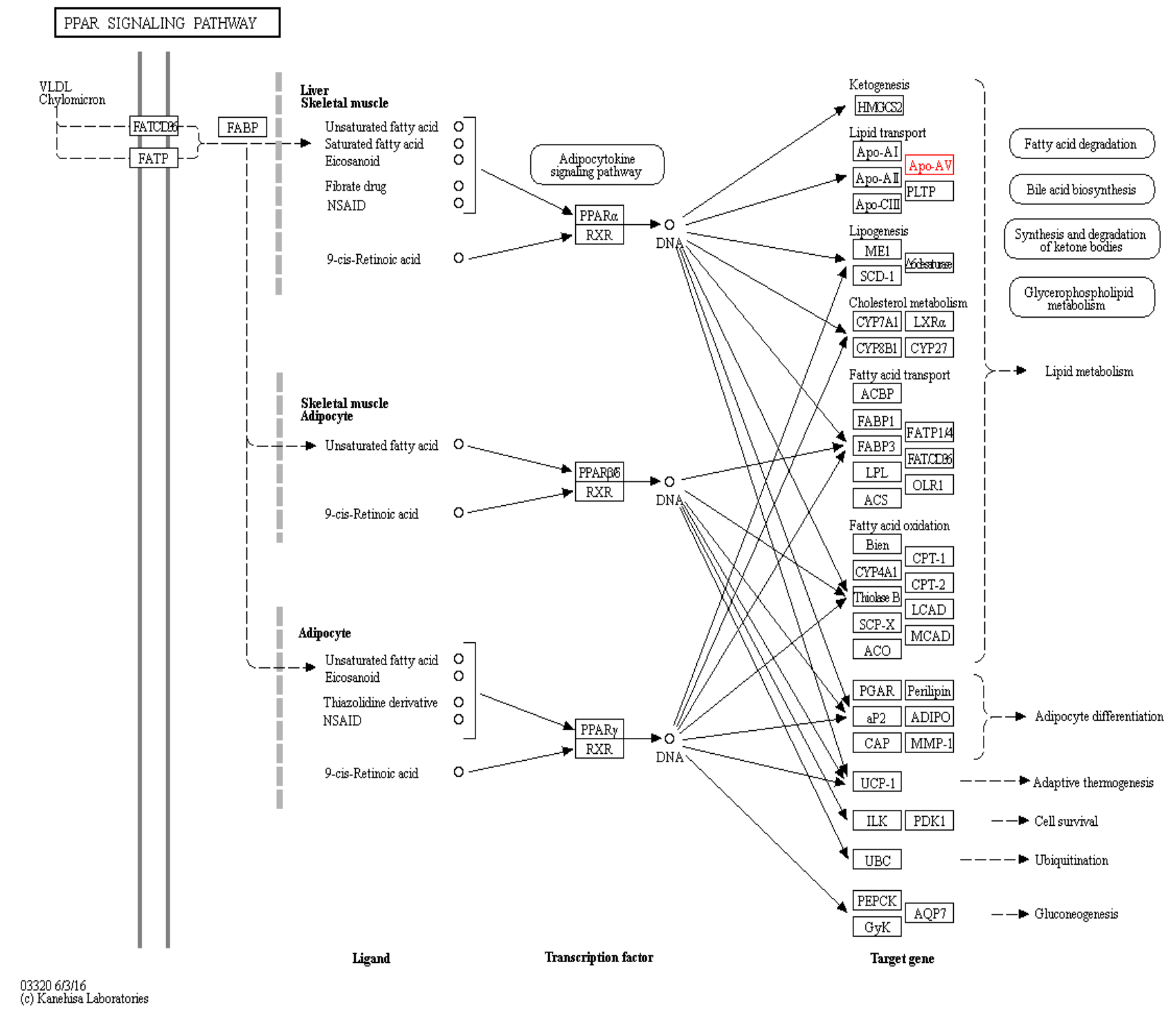

Figure 3. Metabolic pathway of APOA5 gene (KEGG pathway, 2018). $\rightarrow=$ molecular interaction or relation; $--\rightarrow=$ indirect link or unknown reaction; $\mathrm{o}=$ chemical compound, DNA and other molecule

Kim et al. (2017) and Ouatou et al. (2014) reported different SNP positions of APOA5 in human were found that genotype CC had higher frequency compared to CT and TT. In animal, the significant association were reported between SNPs in T635C with abdominal fat weight in F2 cross of White Plymouth Rock x Silkies chicken (Yao et al., 2008). Jiang et al. (2010) confirmed in pig that the significant relationship of SNPs in APOA5 gene were found with body fat deposition in F2 Jinhua $x$ Pietrain population.Furthermore, genome wide association study revealed that APOA5 could be a positional candidate gene for fat deposition in Broiler chickens (Moreira et al., 2018). Three genes (APOA1, APOA4, and APOA5) belong to a gene family (Apolipoproteins -APO) that encodes important regulators of lipid biosynthesis and metabolism (Delgado-Lista et al., 2010). Apolipoprotein A1 (APOA1) is involved in cholesterol transport (Baroukh et al., 2010). While, Apolipoprotein A-IV (APOA4) and Apolipoprotein V (APOA5) are involved with triglycerides metabolism (Delgado-Lista et al., 2010). APOA5 gene may be a functional factor in fat deposition.

The SNP of APOA5 (g.26929941 C>T) was detected in Hardy Weinberg Equlibrium (HWE) $(\mathrm{P}<0.05)$, except JTT sheep. The Hardy Weinberg in equilibrium if the genetic variation, allele, and genotype frequencies in a population remain constant from one generation to the next in the absence of disturbing factors (Allendorf et al., 2013). This study showed that the APOA5 gene polymorphism is associated with lauric acid (C12:0), eicosapentanoic acid (C20:5n3), and docosahexanoic acid (C22:6n3) in combined population (JFT, JTT, and GCS) (Table 3). Consumption of meat containing saturated fatty acids (SFA) lauric acid (C12:0) can produce insulin that is susceptible to insulin resistance, hyperinsulinemia or increase cholesterol production (Cheeke \& Dierenfeld, 2010). High intake of saturated fatty acids (SFA) can cause plasma cholesterol, leading to cardiovascular disease. Eicosapentanoic fatty acids (C20:5n3) and docosahexanoic fatty acids (C22:6n3) are 
fatty acids derived from the essential fatty acids of linoleic acid. Essential fatty acids are the fatty acids needed by the body for the growth and normal function of all tissues that can not be synthesized by the body (Sartika, 2008). In addition, Givens (2010) reported an increased consumption of long chain n-3 PUFA such as eicosapentaenoic (20:5n3) and docosahexaenoic (22:6n3) acids are linked to the development and functionality of nervous, vision, and immune systems and have cardio-protective and anticarcinogenic functions (McAffe et al., 2010; Smit et al., 2009). Consumption of saturated fatty acids (SFA) is limited between 0-10\%, MUFA $16 \%$, PUFA $7 \%$, and cholesterol should not be more than $300 \mathrm{mg}$ per day (USDA, 2010). Furthermore, consumption of SFA, trans MUFA, and cholesterol exceeds normal requirements and has an excess body weight (obesity) were suspected as the cause of disease, such as cardiovascular disease, atherosclerosis, and other diseases (USDA, 2010). Previous study reported by Ouatou et al. (2014) revelead that the polymorphism of APOA5 gene $56 \mathrm{C}>\mathrm{G}$ and $-1131 \mathrm{~T}>\mathrm{C}$ of APOA5 gene in humans play roles in increasing the risk of coronary artery disease due to their associations with increasing plasma tryglyserides (TG).

Apolipoprotein A5 (APOA5) is a recognized regulator of plasma triglycerides (TGs), and previous studies have shown the associations between variants in APOA5 gene and high TG levels (Bertoccini et al., 2017). In humans, APOA5 is expressed almost exclusively in the liver tissue (Pennacchio et al., 2001) and some minor expressions have also been detected in the small intestine (Guardiola et al., 2012). APOA5 has been identified as an important determinant of plasma TG levels in humans and mice since its discovery (Van der Vliet et al., 2001; Pennacchio et al., 2001). Another function of APOA5 could be to regulate the assembly and secretion of intestinal lipoproteins replete with dietary lipids. In support of this function, Guardiola et al. (2012) report that fatty acid affects its expression and, as such, favours its role in TG metabolism in which it is modulated by dietary factors. Fatty acid metabolism is a complex process, which involves lipolysis of dietary fat, biohydrogenation in the rumen and de novo synthesis of FAs by rumen bacteria. Furthermore, absorption and transport of FAs by the host animal, de novo synthesis in the host's tissues, elongation and desaturation in the animal's tissues, hydrolysis of triglycerides and esterification, and the oxidation of FA or its metabolization into the other components (Ekine-Dzivenu et al., 2014; Laliotis et al., 2010).

KEGG pathway analysis has confirmed and visualized the involvement of APOA5 was enriched in peroxisome proliferator-activated receptors (PPARs) signaling pathway (Figure 3). Peroxisome proliferator-activated receptors (PPARs) are nuclear hormone receptors that are activated by fatty acids and their derivatives. Berger \& Moeller (2002) report PPARs are nuclear hormone receptors that are activated by FAs and their derivatives, and play an important role in the regulation of adipocyte tissue development, lipogenesis, and skeletal muscle lipid metabolism. There are three members of the PPAR family (PPARalpha, beta/delta, and gamma) based on KEGG pathway analysis (Figure 3). PPAR alpha involved in lipid metabolism in the liver and in the skeletal muscle, and in the modulation of the inflammatory response. PPAR beta/delta play a role in lipid oxidation and cell proliferation, and acts on embryo implantation, cell proliferation, and apoptosis. PPAR gamma is related to cell cycle withdrawal and promotes myocyte/adipocyte differentiation to enhance blood glucose uptake (Ehrenborg et al., 2009; Kertsen et al., 2008; Berger et al., 2002). Berton et al. (2016) studying RNA seq in Nellore cattle identified the PPAR signaling pathway as the most significantly overrepresented pathway involved in fatty acid composition, suggesting that PPAR would also play a key role in controlling fatty acid metabolism.

\section{CONCLUSION}

The APOA5 gene was polymorphic in Indonesian sheep. The APOA5 (g.26929941C> T) gene was significantly associated with eicosapentanoic acid (C22:6n3), docosahexanoic (C22:6n3], and lauric acid (C12:0)]. This study demonstrated that SNP of APOA5 might contribute for selection of Indonesian sheep with high meat and nutritional quality based on fatty acid composition especially unsaturated fatty acids.

\section{CONFLICT OF INTEREST}

The Authors declare that there is no conflict of interest with any financial, personal, or other relationships with other people or organization related to the material discussed in the manuscript.

\section{ACKNOWLEDGEMENT}

This work was financially supported by KP4S project from Ministry of Agriculture, Republic of Indonesia Fiscal Year 2017 Number: 76.60/PL.040/H.1/04/2017.K date 20 April 2017.

\section{REFERENCES}

Allendorf, F. W., G. Luikart, \& S. N. Aitken. 2013. Conservation and the genetics of populations. John Wiley \& Sons, Chichester.

Almeida, A.M. 2011. The Damara in the context of Southern Africa fat-tailed sheep breeds. Trop. Anim. Health. Prod. 43:1427-1441. https://doi.org/10.1007/s11250-011-9868-3

AOAC. 2012. Official Methods of Analysis. 19th Ed. Association of Official Analytical 240 Chemists, Washington, Arlington, USA.

Aslam, M.L., J.W. Bastiaansen, M.G. Elferink, H.J. Megens, R.P. Crooijmans, L.A. Blomberg, R.C. Fleischer, C.P. Van Tassell, T.S. Sonstegard, S.G. Schroeder, \& M.A. Groenen. 2012. Whole genome SNP discovery and analysis of genetic diversity in Turkey (Meleagris gallopavo). BMC Genomics. 13: 391. https://doi.org/10.1186/1471-2164-13-391

Bahar, B. 2003. Panduan Praktis Memilih Produk Daging Sapi. Jakarta (ID): PT. Gramedia Pustaka Utama.

Barouk, N., E. Bauge, J. Akiyama, J. Chang, V. Afzal, J.C. Fruchart, E.M. Rubin., J. Fruchart-Najib, \& L.A. Pennacchio. 2004. Analysis of apolipoprotein A5, c3, and plasma triglyceride concentrations in genetically engineered mice. Arterioscler Thromb. Vasc. Biol. 24:1297-302. 
https://doi.org/10.1161/01.ATV.0000130463.68272.1d

Berger, J. \& De Moller. 2002. The mechanisms of action of PPARs. Annu Rev Med. 53:409-35. https://doi.org/10.1146/ annurev.med.53.082901.104018

Bertoccini, L., F. Sentinelli, M. Incani, D. Bailetti, F.A. Cimini, I. Barchetta, M.G. Cavallo, E. Cossu, A. Lenzi, S. Loche, \& M.G. Baroni. 2017. The Arg282Ser missense mutation in APOA5 gene determines a reduction of triglyceride and LDL-cholesterol in children, together with low serum levels of apolipoprotein A-V. J Lipids Health. Dis. 16: 179. https://doi.org/10.1186/s12944-017-0569-4

Berton, M.P, L.F. Fonseca, D.F. Gimenez, B.L. Utembergue, A.S. Cesar, L.L. Coutinh, M.V.A de Lemos, C. Aboujaoude, A.S. Perei, M.D.O Rafael, \& N.B. Stafuzza. 2016. Gene expression profile of intramuscular muscle in Nellore cattle with extreme values of fatty acid. BMC Genomics. 17:972. https://doi.org/10.1186/s12864-016-3232-y

Bindea, G., Mlecnik, B, H. Hackl, P. Charoentong, M. Tosolini, A. Kirilovsky, W.H. Fridman, F. Pagès, Z. Trajanoski, \& G. Galon. 2009. ClueGO: a Cytoscape plug-in to decipher functionally grouped gene ontology and pathway annotation networks. Bioinformatics. 25: 1091-1093. https://doi. org/10.1093/bioinformatics/btp101

Caranca-Gonzalez, L., R.B.R. Leon-Cachon, M.A. GonzalezZavala, C. Rios-Ibarra. J. Morlet-Chavez, C. SanchezDominguez, A. Cepeda-Nieto, \& M. Salinas-Santander. 2018. ACE, APOA5, and MTP gene polymorphism analysis in relation to triglyseride and insulin levels in pediatric aptients. Arch. Med. Res. Accepted D-17-00454

Cheeke, P.R. \& E.S. Dierenfeld. 2010. Comparative Animal Nutrition and Metabolism. CABI Publ, Cambridge (US). https://doi.org/10.1079/9781845936310.0000

Chowdhurry, R., S. Warnakula, S. Kunutsor, F. Crowe., H.A Wardd, L. Johnson, O.H. Franco, A.S. Butterwoth, N.G. Fourouhi, \& S.G. Thompson. 2014. Association of dietary, circulating and supplement fatty acids with coronary risk; a systematic review and meta-analysis. Ann. Intern. Med. 160: 398-406. https://doi.org/10.7326/M13-1788

Cinar, M. U., A. Kayan, M.J. Uddin, E. Jonas, D. Tesfaye, C. Phatsara, S. Ponsuksili, K. Wimmers, E. Tholen, C. Looft, H. Jungst, \& K. Schellander. 2012. Association and expression quantitative trait loci (eQTL) analysis of porcine AMBP, GC and PPP1R3B genes with meat quality traits. Mol. Biol. Rep. 39:4809-4821. https://doi.org/10.1007/ s11033-011-1274-4

Delgado-Lista, J., F. Perez-Jimenez, J. Ruano, P. PerezMartinez., F. Fuentes., J. Criado-Garcia., L.D. Parnell., A. Garcia-Rios, J.M. Ordovas \& J. Lopez-Miranda. 2010. Effects of variations in the APOA1/C3/A4/A5 gene cluster on different parameters of postprandial lipid metabolism in healthy young men. J. Lipid Res. 51: 63-73. https://doi. org/10.1194/jlr.M800527-JLR200

Ehrenborg, E, \& A. Krook. 2009. Regulation of skeletal muscle physiology and metabolism by peroxisome proliferatoractivated receptor delta. Pharmacol. Rev. 61:373-93. https:// doi.org/10.1124/pr.109.001560

Ekine-Dzivenu, C., L. Chen, M. Vinsky, N. Aldai, M.E.R. Dugan, T.A. Mcallister, Z. Wang, E. Okine, \& C. Li. 2014. Estimates of genetic parameters for fatty acids in brisket adipose tissue of Canadian commercial crossbred beef steers. Meat. Sci. 96:1517-26. https://doi.org/10.1016/j. meatsci.2013.10.011

Folch, J., M. Lees, \& G.H. Sloane-Stanley. 1957. A simple method for the isolation and purification of total lipids from animal tissues. J. Biol. Chem. 226:497-509.

Fruchart-Najib, J., E. Bauge, \& L.S Nicelascu. 2004 Mechanism of trygeliseride lowering in mice expressing human apoliporotein A5. Biochem. Biophys. Res. Commun. 319:397404. https://doi.org/10.1016/j.bbrc.2004.05.003
Furqon, A., A. Gunawan., N. Ulupi., T. Suryati, \& C. Sumantri. 2017. Expression and Association of SCD Gene Polymorphisms and Fatty Acid Compositions in Chicken Cross. Med. Pet 40:151-157. https://doi.org/10.5398/ medpet.2017.40.3.151

Givens, D.I. 2010. Milk and meat in our diet: good or bad for health? Animal 4: 1941-1952. https://doi.org/10.1017/ S1751731110001503

Givens, I.D. \& R.A. Gibbs. 2008. Current intakes of EPA and DHA in European populations and the potential of animal-derived foods to increase them. Proceedings of the Nutrition Society 67: 273-280. https://doi.org/10.1017/ S0029665108007167

Guardiola, M., A. Alvaro, J.C. Vallve, R. Rosales, R. Sola., J. Girona, N. Serra, P. Duran, E. Esteve, L. Masana, \& J. Ribalta. 2012. APOA5 gene expression in the human intestinal tissue and its response to in vitro exposure to fatty acid and fibrate. Nutr. Metab. Cardiovasc. Dis. 22: 756-762. https://doi.org/10.1016/j.numecd.2010.12.003

Gunawan, A., K. Kaewmala, M.J. Uddin, M.U. Cinar, D. Tesfaye, C. Phatsara, E. Tholen, C. Looft, \& K. Schellander. 2011. Association study and expression analysis of porcine ESR1 as a candidate gene for boar fertility and sperm quality. Anim. Reprod Sci. 128:11-21. https://doi.org/10.1016/j. anireprosci.2011.08.008

Gunawan, A., M.U. Cinar, M.J. Uddin, K. Kaewmala., D. Tesfaye., C. Phatsara., E. Tholen., C. Looft, \& K. Schellander. 2012. Investigation on association and expression of ESR2 as a candidate gene for boar sperm quality and fertility. Reprod. Domest. Anim. 47:782-90. https:// doi.org/10.1111/j.1439-0531.2011.01968.x

Gunawan, A., Jakaria, K. Listyarini, A. Furqon, C. Sumantri, S.H. Akter, \& M.J. Uddin. 2018. Transcriptome signature of liver tissue with divergent sheepmeat odour and flavour using RNA deep sequencing. Gene. 676: 86-94. https://doi. org/10.1016/j.gene.2018.06.086

Jasim, H.A., S.A. Al-Bustan, W. Al-Kandari, A. Al-Seri, \& H. Al-Askar. 2018. Sequence analysis of APOA5 among the Kuwaiti population identifies association of rs2672560, rs2266788 and rs662799 with TG and VLDL level. Front. Gen. 9:112. https://doi.org/10.3389/fgene.2018.00112

Jeong, J, X. Shi, X. Zhang, S. Kim \& C. Shen. 2011. An empirical Bayes model using a competition score for metabolite identification in gas chromatography mass spectrometry. BMC Bioinformatics. 12:392. https://doi. org/10.1186/1471-2105-12-392

Juárez, M., A. Horcada, M.J. Alcalde, M. Valera, A.M. Mullen, \& A. Molina. 2008. Estimation of factors influencing fatty acid profiles in light lambs. Meat. Sci.79:203-210. https:// doi.org/10.1016/j.meatsci.2007.08.014

Kim, M., K. Kim, H.J. Yoo, E. Lee, J.S. Chae, S.H. Lee, J.S. Cha S. Lee \& J.H. Lee. 2017. A promoter variant of the APOA5 gene increases atherogenic LDL levels and arterial stiffness in hypertriglyceridemic patients. PLoS ONE 12: e0186693. https://doi.org/10.1371/journal.pone.0186693

Kersten, S. 2008. Peroxisome proliferator activated receptors and lipoprotein metabolism. PPAR Res. 2008: 132690. https://doi.org/10.1155/2008/132960

Kyoto Encyclopedia of Genes and Genomes. 2018. http://david. abcc.ncifcrf. gov/kegg.jsp?path=bta00650\$Butanoate\%20 metabolism\&termId=470 015001\&source=kegg. Accessed 23 Mei 2018.

Lai, C.Q., D. Correla, S. Demissie, A. Cupples., X. Adiconis, Y. Zhu, L.D. Parnell, K.L. Tucker, \& J. Ordovas. 2006. Dietery intake of n-6 fatty acids modulates effect of apolipoprotein A5 gene on plasma fasting triglyseride, remant lipoprotein concentratio and lipoprotein particle size. Circulation. 113: 2062-2070. https://doi.org/10.1161/ CIRCULATIONAHA.105.577296 
Laliotis, G.P, I. Bizelis, \& E. Rogdakis. 2010. Comparative approach of the de novo fatty acid synthesis (Lipogenesis) between ruminant and non ruminant mammalian species: from biochemical level to the main regulatory lipogenic genes. Curr. Genomics. 11 (Suppl 3):168-83. https://doi. org/10.2174/138920210791110960

Martin, M. L., G. Barceló-Coblijn, R.F. de Almeida, M.A. Noguera-Salvà, S. Terés, M. Higuera, G. Liebisch, G. Schmitz, X. Busquets, \& P.V. Escribá. 2013. The role of membrane fatty acid remodeling in the antitumor mechanism of action of 2-hydroxyoleic acid. Biochim Biophys Acta. 1828:1405-13. https/doi.org/ 10.1016/j. bbamem.2013.01.013.

McAfee, A.J., E.M. McSorley, G.J. Cuskelly, B.W. Moss, J.M.W. Wallace, M.P. Bonham, \& A.M. Fearon. 2010. Red meat consumption: an overview of the risks and benefits. Meat Sci 84: 1-13. https://doi.org/10.1016/j.meatsci.2009.08.029

Moreira, G.C.M., C.Boschiero, A.S.M. Cesae, J.M. Reecy, T.F. Godoy, P.A. Trevisoli., M.E. Cantão, M.C. Ledur, A.M.G. Ibelli, J.O. Peixoto, A.S.A.M.T Moura, D.Garrick, \& L.H. Coutinho. 2018. 'A genome-wide association study reveals novel genomic regions and positional candidate genes for fat deposition in broiler chickens. BMC Genomics 19:374. https://doi.org/10.1186/s12864-018-4779-6

Nei, M. \& S. Kumar. 2000. Moleculear Evolution and Phylogenetics. Oxford University Press, New York.

Orsavova, J., L. Misurcova, J.V. Ambrozova., R. Vicha \& J. Mlcek. 2015. Fatty acids composition of vegetable oils and its contribution to dietary energy intake and dependence of cardiovascular mortality on dietary intake of fatty acids. Int. J. Mol. Sci. 16:12871-90. https//doi.org/10.3390/ ijms160612871

Ouatou, S., M. Ajjemami, H. Charoute, H. Sefri., N. Ghalim., H. Rhaissi, H. Benrahma, H Barakat, \& H. Rouba. 2014. Association of APOA5 rs662799 and rs3135506 polymorphisms with arterial hypertension in Moroccan patients. Lipids Health Dis. 13:60. https://doi. org/10.1186/1476-511X-13-60

Pennacchio, L.A., M. Olivier, J.A. Hubacek, J.C. Cohen, D.R. Cox, J.C. Fruchart, R.M. Krauss, \& E.M. Rubin. 2001. An apolipoprotein influencing triglycerides in humans and mice revealed by comparative sequencing. Science. 294: 169-173. https://doi.org/10.1126/science.1064852

Perez, R., J. Ca-ón, \& S. Dunner. 2010. Genes associated with long-chain omega-3 fatty acids in bovine skeletal muscle. Journal of Applied Genetics. 51: 479-487. https://doi. org/10.1007/BF03208877

Sambrook, J. \& D. Russell. 2001. Molecular Cloning: a Laboratory Manual. 3rd ed. Cold Spring Harbor Laboratory Press, New York.
Sartika, R.A.D. 2008. Pengaruh asam lemak jenuh, tidak jenuh dan asam lemak trans terhadap kesehatan. Jurnal Kesehatan Masyrakat Nasional. 2: 154-160. https://doi. org/10.21109/kesmas.v2i4.258

Siri-Tarino, P.W. S. Chiu., N. Bergeron, \& R.M. Krauss. 2015. Saturated fats versus polyunsaturated fatty fats versus carbohydrates for cardiovaskular disease prevention and treatment. Annu. Rev. Nutr. 35: 517-543. https://doi. org/10.1146/annurev-nutr-071714-034449

Smit, L.A., D. Mozaffarian, \& W. Willett. 2009. Review of fat and fatty acid requirements and criteria for developing dietary guidelines. Annals Nutr. Metab. 55: 44-55. https:// doi.org/10.1159/000228995

Soeparno. 2011. Ilmu dan Teknologi Daging. Ed ke-5. UGM Pr, Yogyakarta (ID).

Sun, L., D. Bai, L. Xiang., G. Zhang., W. Ma \& H. Jiang. 2016. Comparative transcriptome profiling of longissimus muscle tissues from Qianhua Mutton Merino and Small Tail Han sheep. Sci. Rep. 6.

USDA [United State Department of Agriculture] dan USDHHS (United State Department of Health and Human Services]. 2010. Dietary Guidelines for Americans, 2010. 7th ed. Government Printing Off, Washington DC (US).

Van Harten, S., T. Kilminster, T. Scanlon, J. Milton., C. Oldham, J. Greeff \& A.M. Almeida. 2016. Fatty acid composition of the ovine longissimus dorsi muscle: effect of feed restriction in three breeds of different origin. J. Sci. Food Agric. 96: 1777-1782. https://doi.org/10.1002/jsfa.7285

Wilkes, M.J., P.I. Hynd, \& W.S. Pitchford. 2012 Damara sheep have higher digestible energy intake than Merino sheep when fed low-quality or high-quality feed. Anim. Prod Sci. 52:30-34. https://doi.org/10.1071/AN11033

Wina, E. \& I.W.R. Susana. 2013. Manfaat lemak terproteksi untuk meningkatkan produksi dan reproduksi ternak ruminansia. Wartazoa. 23: 176-184.

Yao, J.F., Y. Zhang, G.Q. Wu, J.X. Zheng, X.M. Deng, \& N. Yang. 2008. Polymorphisms of chicken APOA5 gene and association with carcass traits of chickens. Yi Chuan 30:607-612 (In Chinese). https://doi.org/10.3724/SP.J.1005.2008.00607

Yousefi, AR., H. Kohram, A.Z. Shahneh, A. Nik-khah, \& A.W. Campbell. 2012. Comparison of the meat quality and fatty acid composition of traditional fat-tailed (Chall) and tailed (Zel) Iranian sheep breeds. Meat Sci. 92:417-422. https:// doi.org/10.1016/j.meatsci.2012.05.004

Zhang, L.F., X. L. Jiang, X. C. Hua, Y. P. Lu, \& N. Y. Xu. 2010. Molecular cloning, expression and polymorphism of the porcine apolipoprotein A5 gene in a Jinhua3Pietrain F2 reference population. Animal 4:523-529. https://doi. org/10.1017/S175173110999142X 